\title{
Complications of Financial Institution in Promoting Women Entrepreneurs
}

\author{
Jitendra Kumar Chauhan $^{1 *}$ and Pubali Saikia ${ }^{2}$ \\ ${ }^{1}$ Agriculture Extension, College of Post Graduate Studies in Agricultural Sciences, \\ Umiam, Meghalya, CAU, Imphal, Manipur, India \\ ${ }^{2}$ Vidya Bharati College, Kamrup, Assam, India \\ *Corresponding author
}

\section{A B S T R A C T}

Keywords

Complication,

Financial

institution, Women,

Entrepreneurs

Article Info

Accepted:

12 December 2020

Available Online:

10 January 2021
Financial institutions play an important role in promoting entrepreneurship among women. They are the main support system of entrepreneurship development. But it is very difficult to get financial assistance from any financial institution while starting an enterprise. It has been observed that majority of entrepreneurs face lots of difficulties to sanction their loan. Due to poor knowledge regarding bank facilities they face start up problem of enterprise. There are different types of financial institutions for entrepreneurship development among women such as Nationalized Banks, Private Banks and other institutions. The present study was conducted in the state of Assam. The total number of financial institution was 17.

\section{Introduction}

In this study, promotional agency or financial institution is defined as the agency which provides financial and other support services to entrepreneurs. Nationalized banks, private banks and other banks were selected for this investigation. On the basis of advocacy services, training facilities, support services provided to the prospective and continuing entrepreneurs the agencies such as DICC, MSME, IIE and NEDFi were grouped other agencies under promotional agency for the present investigation.
The study would definitely give a meaningful insight to officials of promotional agencies about the current position of women to provide financial as well as other supportive services while sanctioning and granting loan to women entrepreneurs.

Further the study would help officials of aforesaid institutions to change their attitude towards women entrepreneurs. The functional scope of the study is to suggest remedial measures for the successful growth and development of women entrepreneurs. The investigation was carried out with the following objectives include to find out the 
various complications faced by the promotional agencies in performing their role. And also to provide better measures for better performance of the entrepreneurs.

\section{Materials and Methods}

The total number of promotional agency was17 which is the sum total of Nationalized Banks (9), Private Banks (3), Other Banks (3) and Other Agencies (2). "Problem" of promotional agencies is operationalized as difficulties faced by different agencies while providing financial assistance and other supportive services to women entrepreneurs.

\section{Results and Discussion}

The salient findings of the study are summarized below:

\section{Objective-1. Complications faced by promotional agencies}

The data on problems faced by officials of promotional agencies presented in the Table 1 highlighted that officials of Nationalized Banks faced problems lack of understanding of women entrepreneurs about legal procedure of bank and ranked I followed by insufficient capital investment by women entrepreneurs to start an enterprise with rank II.

Other problems such as lack confidence and decision making ability of women entrepreneurs to run an enterprise got equal rank i.e. III in list of problems. This was followed by poor participation in EDP training and by poor involvement of women entrepreneurs in business with IV rank equally. Lack of knowledge of women entrepreneurs in marketing of products and irregular contact with bank officials ranked as V.
Therefore, there is a need to train/ aware women entrepreneurs at all levels of the marketing chain in handling techniques of their enterprise's survive, sustain and success. These should help them to open new doors to expand their enterprises. It is therefore, necessary to involve them on an equal footing with men and this can be done only if women entrepreneurs are given the proper means to improve themselves and their entrepreneurial situation.

The data on different problems faced by officials of Private Banks revealed poor involvement of women entrepreneurs in business ranked I with highest mean snore of 3.33 followed by insufficient capital investment by women entrepreneurs to start an enterprise, lack of understanding of women entrepreneurs about legal procedure of bank, lack of decision making ability ranked II.

The findings in the same Table also indicates that different problems faced by officials of other banks was poor involvement of women entrepreneur in business and got rank I with score of 4.00. Other problem such as poor participation in EDP training by women entrepreneurs ranked II. Common problems faced by bank officials and ranked III equally were insufficient capital investment by women entrepreneurs to start an enterprise, lack of confidence of women entrepreneurs to run an enterprise, lack of understanding of women entrepreneurs about legal procedure of bank and irregular contact of women entrepreneurs with bank officials.

Therefore, it is very much essential for government and non government organization working for development of women entrepreneurs to organize different intervention programme for better performance of entrepreneurs in the enterprise sector. 
Table.1 Ranking of problems faced by financial Institution N=17

\begin{tabular}{|l|c|c|c|c|c|c|c|c|}
\hline \multirow{2}{*}{ Problems/Statements } & \multicolumn{2}{|c|}{$\begin{array}{c}\text { Nationalized } \\
\text { Banks }\end{array}$} & \multicolumn{2}{|c|}{ Private Banks } & \multicolumn{2}{c|}{ Other Banks } & \multicolumn{2}{c|}{ Other Agencies } \\
\cline { 2 - 9 } & $\begin{array}{l}\text { Mean } \\
\text { score }\end{array}$ & Rank & $\begin{array}{c}\text { Mean } \\
\text { score }\end{array}$ & Rank & $\begin{array}{c}\text { Mean } \\
\text { score }\end{array}$ & Rank & $\begin{array}{c}\text { Mean } \\
\text { score }\end{array}$ & Rank \\
\hline Insufficient capital investment & 2.15 & II & 3.00 & II & 3.33 & III & 4.50 & II \\
\hline Lack of confidence & 2.09 & III & 2.83 & III & 3.33 & III & 3.50 & III \\
\hline $\begin{array}{l}\text { Lack of understanding about } \\
\text { legal procedure of bank. }\end{array}$ & 2.21 & I & 3.00 & II & 3.33 & III & 3.50 & III \\
\hline $\begin{array}{l}\text { Lack of decision making } \\
\text { ability. }\end{array}$ & 2.09 & III & 3.00 & II & 2.67 & IV & 3.50 & III \\
\hline $\begin{array}{l}\text { Poor participation in EDP } \\
\text { training }\end{array}$ & 2.04 & IV & 2.83 & III & 3.67 & II & 4.75 & I \\
\hline $\begin{array}{l}\text { Irregular contact with bank } \\
\text { officials }\end{array}$ & 2.01 & V & 2.33 & IV & 3.33 & III & 3.50 & III \\
\hline Poor involvement in business & 2.04 & IV & 3.33 & I & 4.00 & I & 2.50 & IV \\
\hline Poor utilization of man power & 2.00 & VI & 2.30 & V & 3.33 & III & 3.50 & III \\
\hline
\end{tabular}

The most common problem faced by officials of other agency was poor participation in EDP training by entrepreneurs with rank I, insufficient capital investment by women entrepreneurs to start an enterprise ranked II, lack of confidence of women entrepreneurs to run an enterprise, lack of understanding of women entrepreneurs legal procedure of bank, lack of decision making ability of women entrepreneurs, irregular contact of women entrepreneurs with bank officials and lack of knowledge of women entrepreneurs in marketing of products, poor utilization of man power equally ranked III with score of 3.50in the list of problems.

Therefore, it is very much essential to provide right efforts to draw the attention of entrepreneurs about the various facilities of supportive institutions to recognise the entrepreneurial talents in the global platform.

\section{Objective-2. Better suggestions for women entrepreneurs}

Suggestive measures for better performance of women entrepreneurs are as follows-
Contact with legal adviser would benefit the entrepreneurs to make them aware about legal formalities of bank.

Participation in entrepreneurship development training programme (EDP) would be more effective for entrepreneurs to continue their entrepreneurial activities. Because EDP training programme organized by DICC, MSME and IIE would help entrepreneurs for overall management and development of their entrepreneurial works right from starting to marketing of various products.

Entrepreneurs should encourage contacting officials of promotional agencies regularly to solve their varieties of problems encountered while starting and running their micro enterprises.

In conclusion the government must put forward a pressure to promotional agencies to provide financial assistance in a limited time frame for their successful growth. Concluding the scenario of growth of entrepreneurship of women in rural area is a critical concern. Therefore, there is a need for continuous attempt to inspire, encourage, motivate and 
co-operate with women entrepreneurs conducting of awareness programmes should be conducted on a mass scale with the intention of creating awareness among women about the various aspects to conduct different business. The findings of this study have implications for entrepreneurs as well as the policymakers who work for the improvement of entrepreneurs.

At present women have broken the monopoly of men and proved that they are not inferior to men. Micro enterprises have major impact on social and economic life of rural women. The study concludes that there was an increase in self-confidence, self-reliance and independence of rural women due to involvement in the entrepreneurial and other activities. Now women entrepreneurs are aware of opportunities available to them, but there is scope for further improvement in it.

\section{References}

Balu, V. (1998). Women entrepreneurship in India- Problems and prospects. Third Concepts, 29 (139): 39-41.

Cantillon, R. (1730). Essai Sur la Narure commerce en General (originally published in French language in 1730), quoted from Misra, P.N., Development Banks and the new entrepreneurship in India, New Delhi, National Publishing House, p. 8.

Chisom, A.N. (2012). Loan granting and its recovery problems on commercial banks. A case study of first Bank PLC, OJO- ALABA Branch. B.Sc. degree in Banking and Finance, Department of Banking, Faculty of Management and Social Science, Caritas University, Amorji-Nike Emene, Enugu State, pp. 1-59.

Das, M.(2012). Women empowerment through entrepreneurship: A case study of Guwahati municipal corporation, Intern. R. J. Comp. Appl. Eng. Sc.2(1): 27-29.

Loan granting and its recovery problems on Commercial banks (a case study of first bank plc, ojoalaba branch ) file://C:/Users/Dr.\%20M.B.\%20Deka/ Downloads/LOAN\%20GRANTING\%2 0AND\%20ITS\%20RECOVERY\%20P ROBLEMS\%20(1).pdf

Government measures and institutions in support of women entrepreneurship http://shodhganga.inflibnet.ac.in/bitstrea m/10603/367/12/12_chapter4.pdf

\section{How to cite this article:}

Jitendra Kumar Chauhan and Pubali Saikia. 2021. Complications of Financial Institution in Promoting Women Entrepreneurs. Int.J.Curr.Microbiol.App.Sci. 10(01): 1872-1875. doi: https://doi.org/10.20546/ijcmas.2021.1001.219 